This content is available online at AESA
e-ISSN: $2456-6632$

\title{
Position of farmers in agriculture 4.0: Finding from farmers partner of aggregator online vegetables commodity in Indonesia
}

\author{
Janita Meliala* ${ }^{1^{*}}$ (D) , Musa Hubeis ${ }^{2}$, Siti Jahroh ${ }^{3}$ and Agus Maulana ${ }^{4}$ \\ ${ }^{1,3,4}$ School of Business, Bogor Agricultural University, Jalan Pajajaran, Bogor, INDONESIA \\ ${ }^{2}$ Management Department, Economics and Management Faculty, Bogor Agricultural University, Dramaga, Bogor, INDONESIA \\ *Corresponding author's E-mail: janita@binus.ac.id
}

\section{ARTICLE HISTORY}

Received: 23 August 2019

Revised received: 01 September 2019

Accepted: 06 September 2019

\section{Keywords}

Agriculture 4.0

Market

Material

Online aggregator

Position of farmers

\begin{abstract}
The idea of the agricultural revolution 4.0 emerged as the impact of the industrial revolution 4.0. Agriculture 4.0 is characterized by precision agriculture, artificial intelligence, plant factories, and digital marketing. In Indonesia since 2015, online Aggregators have begun to appear in agriculture, which are intermediary actors using internet-based applications or websites that act as liaison for farmers with markets, suppliers and funders. This online aggregator also acts as a mobilizer for partner farmers towards agriculture 4.0. But problems appear when farmers are not ready to face increasingly rapid technological advances. The purpose of this study was to explore the farmer's position towards agriculture 4.0, especially partner of aggregator online vegetable commodities. This study used survey methods to collect information from farmers used questionnaire. Sampling method used the quota sampling to select 36 farmers from 12 aggregators online vegetables commodity. Analysis of the position of farmers using the questionnaire based on indicators on the 6 elements of management are man, material, method, machine, money, market in agricultural positions 1.0 to position 4.0. The results of the questionnaire are then processed based on the arithmetic mean. The results showed the position of aggregate partner farmers in general were able to pass the phase of the agricultural revolution 3.0 towards agriculture 4.0. The findings of this study show elements come near to the agricultural 4.0 position are market and material element with an average value 3,83 and 3,56 . While the lowest element position with an average position value of 2.94 is machine.
\end{abstract}

(C)2019 Agriculture and Environmental Science Academy

Citation of this article: Meliala, J., Hubeis, M., Jahroh, S. and Maulana, A. (2019). Position of farmers in agriculture 4.0: Finding from farmers partner of aggregator online vegetables commodity in Indonesia. Archives of Agriculture and Environmental Science, 4(3): 300-306, https://dx.doi.org/10.26832/24566632.2019.040307

\section{INTRODUCTION}

The industrial revolution is marked by technological advances to create effectiveness and efficiency. The fundamental characteristic that determines the existence of the industrial revolution towards 4.0 is automation in every production process especially in the manufacturing and logistics industries (Popkova et al., 2019). The Industrial Revolutionary Era was marked by artificial intelligence, super computers, genetic engineering, nanotechnology, automation, and innovation. All this is happening because technology 4.0 has disrupted the old technology. Technology disruption also penetrated into conventional agriculture which began to utilize artificial intelligence technology, robots, internet of things, drones, block chain, and big data analytics, to produce superior, precise, efficient, and sustainable products or can be said with the term agriculture 4.0 (Matthieu et al., 2018; Braun et al., 2018; Popkova et al., 2019).

The scope of agriculture affected by Agriculture 4.0 includes precision farming that starts with producing superior seeds based on bioinformatics, intelligent integrated pest control with artificial intelligence, precision fertilization, use of smart tractors, seed seeding with robots and the plant factory, off-farming which not only talks about smart agro-industry but also digital agricultural logistics systems. Block chain technology has also 
begun to be applied to ensure transparency and track record of the flow of agricultural products from upstream to downstream so that they can control one another. Digital marketing is used to deal with consumers who are now starting to get used to buying agricultural products online using smartphones. However, the current agriculture conditions in Indonesia showed the advanced conditions of technological revolutions become a threat since the readiness of the main actors involved, farmers were not there yet in advancing agriculture to face the era of technological disruption (Shodiq, 2019; Popkova et al., 2019).

The scope of agriculture that is easy to observe in seeing the readiness of Indonesian agriculture to deal with Agriculture 4.0 is digital marketing. Nowadays, aggregators are starting to develop using the internet / online as a modern actor who acts as an intermediary to channel agricultural products digitally. Farmers' readiness to face changes in adapting to information technology and implementing it requires serious attention. Modern intermediary's namely online aggregators in this study are farmers 'intermediaries with markets, farmers' intermediaries with agricultural machine tool providers, fertilizers, seeds and agricultural capital. Intermediaries here also play a role as a liaison and also play a role in providing information in the form of knowledge about agricultural technology as well as prices and market demand for agricultural commodities. As the name implies, this aggregator uses applications on mobile phones and websites using the internet network in its business activities, so farmers are required to understand and are accustomed to using information technology in this case smart phones that are connected to the internet / online network (Matthieu et al., 2018; Shodiq, 2019).

Popkova et al. (2019) explain the step of industrial revolution. The emergence of steam engines in the 18th century has succeeded in accelerating the economy drastically which in the period of two centuries has been able to increase the income per capita of countries in the world to six fold. The second industrial revolution is known as the Technological Revolution. This revolution was marked by the use and production of iron and steel on a large scale, the widespread use of steam power, telegraph machines. In addition, petroleum was discovered and used extensively and the initial period of electricity was used. In the third industrial revolution, the manufacturing industry has turned into a digital business. Digital technology has dominated the media and retail industries. The third industrial revolution changed the pattern of relations and communication in contemporary society. This revolution has shortened distance and time, this revolution put forward the real time side. The industrial revolution also had an impact on the industry in agriculture. The agricultural industry underwent several changes in the era, starting from traditional agriculture to developing until the digital age agriculture. Agriculture 4.0 is an agricultural revolution with science and technology (IPTEK), it can be from the demand side and supply chain / equal value. Matthieu et al. (2018) revealed that new technologies and solutions in Agriculture 4.0 must be able to give hope to challenges in meeting food needs. Matthieu et al. (2018) explains that there are three general trends related to disruption technologies in the agricultural industry, namely: Producing something different using new techniques. The use of new technology to produce food production to consumers to increase efficiency in the food chain. Involves cross-industry technology and applications. The online aggregator is an intermediary that has just begun to emerge in Indonesia that will encourage agriculture 4.0. According to Soekartawi (2007), e-marketing in agriculture will rapidly developed in the future. This is indicated by the number of agricultural commodity business that already have a website, the number of promotion requests or sales of agricultural commodities advertised on the internet, and the number of transactions for buying and selling agricultural commodities via the internet. Several studies reveal the low use of digital or internet-based information technology by horticultural farmers in Indonesia due to the average age of farmers, traditional farming methods and concerns about the use of new technologies, and low education (Shodiq, 2019). In addition, factors such as lack of ability to use information communication technology (ICT), lack of awareness of the benefits of ICT, too difficult to use, lack of technological infrastructure, high technology costs, low levels of trust in ICT systems, lack of ICT application training, and the low availability of software which causes the low use of ICT at the farm level (Taragola and Gelb, 2012). Based on this problem, the purpose of this study is to find out the position of farmers online aggregator partners used indicators of farm management in agriculture 1.0, 2.0, 3.0 and 4.0.

\section{MATERIALS AND METHODS}

This research was conducted in February-April 2019. In this study use survey method, online aggregator companies were studied as many as 12 online aggregator (Table 1). The sampling technique in this study was conducted by using Quota Sampling, which is 3 (three) farmers from each aggregator company, so that the total respondent of farmers totaled 36 farmers. The type of data used in this study was primary data that obtained through structured interviews with partner farmers of aggregator company that mention in Table 1 with the help of questionnaires.

\section{The indicator of agriculture revolution}

The increasing demands of farmers' families cause them to be faced with the demands for information on modern farming to improve the ability (business management) of farmers to develop farming and produce products that are competitive with the characteristics of farmers behaving efficiently. The method to identifying the position of the aggregator partner farmers based on the indicators that characterize the stages of the agricultural revolution. The basis for determining these indicators refers to the element of management better known as "6M" or "The Six M's in Management". These elements are the most important and absolutely necessary part of management, both in the framework of the process of achieving overall goals or achieving the objectives of each management function implementation. The management elements (Indrawati, 1988) "6M" consists of: 
Table 1. Aggregator online vegetables commodity.

\begin{tabular}{lll}
\hline No & Company name & Website \\
\hline 1. & Sayurbox & www.sayurbox.com \\
2. & Keranjang sayur & www.keranjangsayur.com \\
3. & PT Mandala Agro Persada Nusantara & www.sayours.co.id \\
4. & PT Insan Agritama Teknologi & www.inagri.asia \\
5. & Pak Tani Digital & www.paktanidigital.com \\
6. & Kecipir & www.kecipir.com \\
7. & Sikumis & www.sikumis.com \\
8. & KORPRI Jawa Tengah & www.regopantes.com \\
9. & Etanee & www.etanee.co.id \\
10. & iGrow & www.igrow.asia \\
11. & Tanihub & www.tanihub.com \\
12. & Kedai Sayur & www.kedaisayur.com \\
\hline
\end{tabular}

\section{Humans (Men)}

Humans are the most important supporting element in management because basically management is carried out by humans. Without the activities carried out by humans the organizational goals will certainly not be achieved, but humans themselves must be supported by other elements so that the objectives to be achieved can be fulfilled.

\section{Money}

Money is a tool or the second element after humans, because money is used for the implementation of work and the implementation of all the functions of the leadership in order to achieve goals correctly. Money is also used for stimulants, the intention is to give rewards to the human element and as a management tool so that goals are achieved

\section{Facilities / materials (Materials)}

In the organization and material management is interpreted as a source needed for the implementation of leadership functions and also for the achievement of organizational goals so that organizational goals are not interrupted in the middle of the road. Material here also means physical (raw material) and non-physical (data and information).

\section{Machine}

The role of machines in human life is very much needed because there is a possibility of labor, sickness, neglect and other sources of labor to overcome this machine is a source that is needed in the framework of management processes or work procedures correctly in obtaining maximum results.

\section{Method}

Implementation of the company's activities need to make alternative methods so that the desired product is achieved because the method itself is a verb of the implementation of the right work on a series of activities carried out by humans to follow the development of science that offers a variety of new methods that are faster and better in producing goods or service.

\section{Market}

The market is a place for businesses to expand their activities and marketing. Managers must have a marketing orientation (service users) with a micro and macroeconomic approach and take into account new trends that will involve customer demand or needs. Agricultural revolution will not be separated from the element of management, which can be seen from every stage of the agricultural revolution there is a change in the way farmers manage their businesses. Agriculture 1.0 is characterized by traditional agriculture. Traditional agriculture does not offer sufficient income only to meet the needs of the farmers themselves or can be said to be subsidies (Soekartawi et al., 2007). Agricultural products are used for personal consumption so that the role of trade in the agricultural 1.0 does not yet exist and there is no down streaming process. Agriculture began to develop in the 1960s marked by fundamental changes in the use of agricultural cultivation technology or often called the green revolution. This is motivated because of the challenges of world food limitations. The green revolution is characterized by mass production, the use of fertilizers and pesticides (chemicals), irrigation technology and genetic diversity (Moore and Parai, 1996). After decade, food production faced challenges such as producing healthful, safe and affordable food; reducing pollution and greenhouse gas emissions; developing food chains driven by renewable energy and recycled nutrients; adapting to climate change; and protecting soils, water, air, biodiversity and landscapes. Organic agriculture can help in tackling these future challenges and was named Organic Agriculture 3.0 (Rahman et al., 2017).

The agricultural revolution continues to follow the development of the industrial revolution up to the era of disruptive technologies. Altedinova (2016) revealed that a new era of disruptive technologies had a major impact on innovation in the agricultural sector. In addition, the increasing demands of farmers' families have resulted in demands for farmers to obtain information about modern farming so that can be increasing the ability (business management) of farmers to develop farming and produce competitive products. This research used 6 (six) elements of business management in agriculture namely man, market, money, material, method, and machine as indicators to indicate the position of agriculture 1.0 to agriculture 4.0 (Table 2).

Measurement of the position of farmers using the basic elements of management, and each of these elements there are four indicators that indicate the stage of the agricultural revolution. The answers from each respondent were given a score in accordance with the conditions of the farmer during the interview. Then the answers from each respondent are calculated by the average method for each element. The average score is used as a reference to the position of farmers in the agricultural revolution stage. 
Table 2. Indicators of farmer position in the agricultural era 1.0 to agriculture 4.0.

\begin{tabular}{|c|c|c|c|}
\hline No & $\begin{array}{l}\text { Management } \\
\text { Elements }\end{array}$ & Stage & Indicator \\
\hline \multirow[t]{4}{*}{ A. } & Man & 1 & I manage my own business, assisted by my family \\
\hline & & 2 & I manage a business helped by farmers / other employees \\
\hline & & 3 & I manage the business with an organizational structure that outlines each responsibility \\
\hline & & 4 & I cultivate agriculture with little labor and use high technology \\
\hline \multirow[t]{10}{*}{ B. } & Money & & Asset \\
\hline & & 1 & I do not calculate the business capital that I run, and based capital from personal \\
\hline & & 2 & I borrowed farming capital from my close relatives to increase production \\
\hline & & 3 & I got a capital loan from a financial institution and government assistance \\
\hline & & 4 & I get capital from online transactions \\
\hline & & & Financial management \\
\hline & & 1 & I do not keep records of expenses or income from farming operations \\
\hline & & 2 & $\begin{array}{l}\text { I made a simple bookkeeping to calculate expenses and receipts from the results of farm } \\
\text { operations that are run }\end{array}$ \\
\hline & & 3 & I do financial management \\
\hline & & 4 & I use the application to manage financial business \\
\hline \multirow[t]{4}{*}{ C. } & Marketing & 1 & $\begin{array}{l}\text { There is no marketing but self-consumption, barter system, trading system has not been formed } \\
\text { in an ideal manner }\end{array}$ \\
\hline & & 2 & $\begin{array}{l}\text { There is already marketing, trading system has been formed but is not efficient, selling the } \\
\text { number of products and quality according to the manufacturers' glasses }\end{array}$ \\
\hline & & 3 & Utilizing information technology, the quantity and quality sold according to consumer demand \\
\hline & & 4 & Utilizing the internet of things (iot), building closeness / relationship with consumers. \\
\hline \multirow[t]{4}{*}{ D. } & Material & 1 & I use what is available in nature to get agricultural products \\
\hline & & 2 & I use chemical fertilizers so that the plants I work on can provide a high amount of harvest \\
\hline & & 3 & I started to plant the garden which is organic \\
\hline & & 4 & I do genetic engineering to get superior seeds that produce high productivity \\
\hline \multirow[t]{4}{*}{ E. } & Method & 1 & I do business based on knowledge gained from ancestors \\
\hline & & 2 & I gained knowledge on how to manage a farming business from an agricultural instructor \\
\hline & & 3 & $\begin{array}{l}\text { I find out for myself information related to good and efficient farm management methods from } \\
\text { various media }\end{array}$ \\
\hline & & 4 & I developed my own method of farming management based on technological progress \\
\hline \multirow[t]{4}{*}{$\mathrm{F}$} & Machine & 1 & $\begin{array}{l}\text { Limited information regarding knowledge and technology regarding cultivation and off-farm } \\
\text { aspects }\end{array}$ \\
\hline & & 2 & Use of machinery to increase productivity (co. Tractor) \\
\hline & & 3 & - \\
\hline & & 4 & Drone Technology \\
\hline
\end{tabular}

Note: 1: agriculture 1.0; 2: agriculture 2.0; 3: agriculture 3.0; 4: agriculture 4.0.

\section{RESULTS AND DISCUSSION}

According to the concept of European Agricultural Machinery (2017), agriculture also developed five stages in the development process:

(i) Agriculture 1.0 appeared in the early 20th century, a laborintensive system of agriculture with low productivity;

(ii) Agriculture 2.0 widely remembered as the Green Revolution, this phase of farming began in the late 1950s when agronomic management practices like supplemental nitrogen and new tools like synthetic pesticides, fertilizers and more efficient specialized machines allowed to take advantage of relatively cheap inputs, thus dramatically increasing yield potential and growing returns to scale at all levels;

(iii) Agriculture 3.0, its focus is moved from pure efficiency in terms of cutting costs to profitability which can be seen as objectively and creatively seeking ways to lower costs and enhance the quality or develop differentiated products;

(iv) The evolution of agriculture 4.0 happens in parallel with similar evolutions in the industrial world, where it is marked as industry 4.0. Accordingly, the term agriculture 4.0 is often used in farming. In terms of definitions, agriculture 4.0, in analogy to industry 4.0, stands for the integrated internal and external networking of farming operations. This means that information in digital form exists for all farm sectors and processes; communication with external partners such as suppliers and end customers is likewise carried out electronically; and data transmission, processing, and analysis are automated. Agriculture 4.0 paves the way for the next evolution, including the present operation without direct human and system-based devices that can make decisions automatically.

(v) Agriculture 5.0: This will be based on robotics and (some form of) artificial intelligence. The 36 partner farmers from 12 business aggregators were interviewed using the indicators in table 2 . The results of the $6 \mathrm{M}$ element are processed using the average method or often referred to as mean is the method most widely used to describe the size of the central tendency. The mean is calculated by adding up all the values of the results of the farmer's position check then divided by the number of data / the total number of farmers interviewed, 36. The results of the interview can be seen in Figure 1 below. 


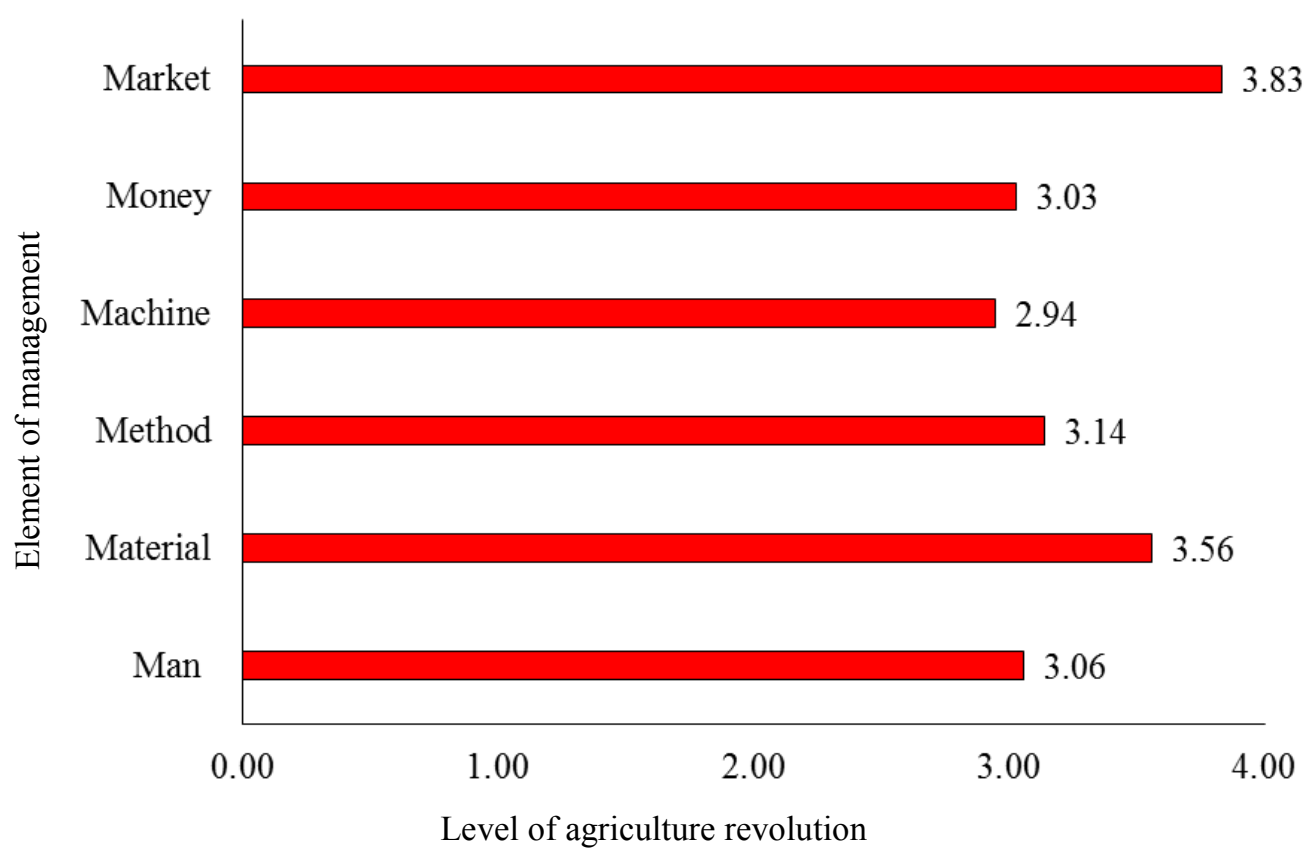

Figure 1. The position of farmers of aggregator online towards agriculture 4.0.

Man

Man refers to the human resources owned by the organization, and man is the person who moves and carries out activities to achieve organizational goals. In the element of man indicator that shows the position of farmers based on the level of agricultural revolution including the first is traditional agriculture, farmers usually work on land only to the extent that can be managed by family labor without the need for paid labor or can be said of subsistence farming (Kusmiadi, 2014), secondly managing businesses are assisted by farmers / other employees, and thirdly manage businesses with an organizational structure that outlines each responsibility or it can be said that human resources (Man) have implemented organizational management well (Creutzberg, 2015). Based on the results of the analysis shows that the Man element is at 3.06 which means most of the aggregate partner farmers have been at the stage of being able to manage businesses based on an appropriate organizational structure or it can be said that the majority of aggregate partner farmers have passed the third agricultural revolution. In the digital age the agricultural sector will significantly change the nature of work and the demand for labor skills. Digital literacy will be a requirement in employment in the agriculture industry and appropriate education and training will also be needed (Nikola et al., 2019). However, the number of farmers who have used digital technology, especially information technology, is still relatively low. Informatics in 2015 the use of Information and Communication Technology (ICT) by households and individuals in Indonesia in 2014 showed that most ICTs are still used for entertainment purposes, as well as the use of the internet, more widely used to access social media.

\section{Material}

To achieve better results in agricultural cultivation, in addition to humans who are experts in their fields must also be able to use materials or materials as a means. In the early days of traditional farming, ancestors used what was available in nature to obtain agricultural products (Yudiarini, 2011). Then, food needs are getting higher because of a surge in population growth comes the innovation of using chemical-based materials (the use of synthetic fertilizers and pesticides) to increase productivity or known by the era of mass production (Sideridis, 2010; European Agricultural Machinery, 2017). Awareness of the dangers of chemicals against environmental damage began to emerge with the idea of organic farming and even in the era of technological disruption now emerging genetic engineering technology and technology capable of controlling plant disease pests via smartphones (Matthieu et al., 2018). At present the position of farmer business partner aggregator has passed through the third stage towards the fourth stage (with the point is 3.56), Farmer partner aggregators are required to produce environmentally friendly products. This is because consumers' concerns about food safety, quality and nutrition are becoming increasingly important, and increasing business opportunities in organic food products (Luqman et al., 2019). Online aggregators that are connected with consumers and have important information related to consumer needs, so that online aggregator partners are also required to produce.

\section{Method}

The method is a systematic procedure or steps to carry out the work. In the early stages of farming, farmers do business based on knowledge gained from their ancestors (Yudiarini, 2011). But the gap between rural and urban areas is getting bigger, this is the role of agricultural extension workers. Agriculture instructors are expected to be able to encourage farmers to have the ability to find and choose information that is suitable to meet 
their needs and opportunities, as well as to have adaptation of innovations to the farmers' environment (Haryanto et al., 2017). Advanced information and communication technology has an impact on the lives of farmers where they can more easily access information about better and more efficient farm management methods. Based on the result of the analysis the point for Method is 3.14. This shows that most of the aggregate partner farmers have used electronic media to gain new knowledge in farming. The lack of agricultural inputs and small farm size are considered important issues in food security (Jabo, 2017). Agriculture 4.0 is expected to increase the efficiency and yield of agriculture by using the internet from things that will make it easier for farmers to get information about agricultural inputs and technology farming methods to overcome the size of small farms.

\section{Machine}

The machine is used to provide convenience or produce greater profits and create work efficiency. At the beginning of the cultivation period, cultivation technology was still low due to limited information about knowledge and technology regarding cultivation and off-farm aspects so that the productivity and quality produced was very low. (Yudiarini, 2011). In the next stage, the use of machinery began to be applied to increase productivity such as tractors (Creutzberg, 2015). At present agriculture is undergoing a fourth revolution triggered by an exponential increase in the use of information and communication technology (ICT) (Walter et al., 2017). Robotic devices have been developed for agricultural purposes, such as mechanical weeding, fertilizer application, or harvesting processes. But, the result shows that the average farmer just reached point 2.94 , indicated by the majority of farmers not yet using many machines to process their farming business or still using traditional farming tools.

\section{Money}

Money is literally interpreted as a medium of exchange. Money is an element of management and can also be interpreted as financial management. Indicators on the Money element are categorized into two namely capital, and financial management. In the category of capital indicators that characterize the level of agricultural revolution include 1) the absence of a clear calculation of my venture capital and is generally obtained from my own capital, 2) there is an effort to obtain capital from other parties, 3) good business management to obtain loans capital from financial institutions, and 4) get capital from online transactions or be swallowed by crowdfunding. Crowdfunding emerged as an alternative tool to finance early stage businesses and businesses that were in the expansion stage (Allison et al., 2014). Crowdfunding also facilitates the financing process by providing an online platform that allows small investors and individuals to invest both small and large amounts (Steinberg, 2012). Crowdfunding is a solution to the capital problems for farmers, namely formal financial institutions that are less interested in financing the agriculture sector because they are considered high risk. But at the moment the online partner aggregator farmers still don't know much about crowdfunding that is asked by an average score of only 3.03. Most online farmer partner farmers rely on formal financial institutions and private capital. As for those who already know about crowd funding, they just don't want to use the service.

\section{Market}

In the past, marketing of agricultural products has not been formed in an ideal manner where farming products are consumed alone or are limited to bartering with other agricultural products (Kusmiadi, 2014). Along with the development of the era or entering the era of mass production, marketing of agricultural products began to form, but not yet ideally where product marketing at that time refers to centric products. The more advanced information technology changes marketing patterns because information related to market needs is increasingly easy to obtain. Currently developing internet technology (internet of things) which is not only limited to marketing products, but also build closeness with consumers (Matthieu et al., 2018). Along with increasing consumer awareness and interest in the community food system over the past decade, facilities and infrastructure that support this system have also grown (Dillemuth and Hodgson, 2016). In addition to direct face-toface transactions where producers sell directly to consumers (such as farmers' markets or roadside kiosks), significant developments are now taking place in intermediary markets, where food collectors, processors and distributors help get local food products from farmers (Reardon and Timmer, 2012). This intermediary provides important facilities, infrastructure, and services that enable small and medium farmers to continue to grow and be able to strengthen local and regional food systems. The actor acting as the intermediary is the aggregator.

Food product aggregation is an important concept and function in local and regional food systems (Dillemuth, and Hodgson, 2016). Aggregation refers to bringing together products from various sources to create a bigger and more consistent supply to meet consumer demand. This requires coordinating product sources from different producers to build reliable supply chains for different end markets such as restaurants and other food service providers, grocery stores, or wholesalers and institutions (for example, schools, hospitals, company cafeterias). Digital technology also has the potential to offer consumer's greater transparency regarding how their food is produced (Nikola et al., 2019). Aggregators who utilize this digital technology are currently developing. In general, farmers who are the object of study are online aggregator farmers, so most farmers have used digital technology to market their agricultural products (shown by scores 3.83). Farmer partners benefit greatly from having an online aggregator in the form of a fair price and the certainty of absorbing agricultural products. Access to digital technology can offer significant benefits to smallholders and other rural businesses by providing links to suppliers, utilizing professional workforce, building strategic partnerships, accessing support services such as training, finance and legal services and most importantly reaching out to markets and customers (Nikola et al., 2019). Farmer partners also revealed the difficulty faced by 
online aggregator partners, among other things, that the quantity of demand from aggregators was relatively lower than the quantity from non-online intermediaries. This is partly because customers from online aggregators are still relatively low. In addition, the distance of delivery of agricultural products which is quite far also becomes an obstacle for partner farmers because the majority of consumer locations are in urban areas.

\section{Conclusion}

Farmers in Indonesia, in this case the sample taken are 36 partner farmers from online aggregators of vegetable commodities which are categorized as having more technological literacy compared to other farmers who are not yet familiar with online aggregators to market their products. 2 Indicators that are approaching the position of agriculture 4.0 are market and material. Where Farmers online aggregator partners have sold their products using websites or applications on their smartphones with internet networks and agricultural materials have also adjusted to the desires of the online vegetable market in the form of organic and fresh vegetables with high quality. While the lowest element position with an average position value of 2.94 is machine, which have not entered the agricultural position 3.0. This research shows that farmers must modernize their agricultural machinery equipment. This needs support from the government. Modern agricultural machines change the mindset of farmers from traditional farming to modern farming. Agricultural businesses have become more efficient, can increase farmers 'incomes, reduce production costs, and increase productivity so as to improve farmers' welfare. Limitation of this research is only examines the position of farmers of online vegetable aggregator partner where the overall position of farmers in Indonesia is very interesting to study in further research because of the results of interviews with online aggregator owners, it is found that they are still having trouble getting farmers partners who are familiar using internet-based information technology.

Open Access: This is an open access article published under the terms and conditions of Creative Commons AttributionNonCommercial 4.0 International License which permits noncommercial use, distribution, and reproduction in any medium, provided the original author(s) if the sources are credited.

\section{REFERENCES}

Allison, T.H., Davis, B.C., Short, J.C. and Webb, J.W. (2014). Crowd funding in a Prosocial Microlending Environment: Examining the Role of Intrinsic Versus Extrinsic Cues. Entrep. Theory Pract, 39: 53-73.

Altedinova, AA. (2016). Innovative development of the agro-industrial complex on the basis of disruptive technologies. St. Petersburg State Polytechnical University Journal, 5(252): 47-56

Shodiq, A.R. (2019). Analysis the Using of E-Marketing by Farmers in Agribusiness
Product Marketing (E-Marketing Case: Tani Niaga Managed by Agriculture Office of Grobogan Regency, Central Java). [thesis]. Bogor Agricultural University.

Braun, A.T., Colangelo, E. and Steckel, T. (2018). Farming in the era of Industrie 4.0. Procedia CIRP, 72 (2018): 979-984

Creutzberg, G. (2015). Agriculture 3.0: A New Paradigm for Agriculture. Nuffield Canada

Dillemuth, A. and K. Hodgson. (2016). Food Aggregation, Processing, and Distribution. In Kimberley Hodgson and Samina Raja (Series Editors), Planning \& Policy Briefs. Growing Food Connections. 9p. Retrieved July 132019 from growingfoodconnections.org

European Agricultural Machinery. (2017). Digital Farming: what does it really mean? and what is the vision of Europe's farm machinery industry for Digital Farming?. Retrieved December, 122018 from https://www.cema-agri.org/ position-papers/254-digital-farming-what-does-it-really-mean

Indrawati, I. (1988). Management and Organization. Second Ed, CV Armico, Bandung.

Jabo, M.M., Ismail, M. Mansor, Shamsudin, Mad. Nasir and Abdullah, Amin, M. and Abdullahi, Y.A. (2017). Food insecurity in rural Nigeria during the lean season: Causes and coping strategies. Archives of Agriculture and Environmental Science, 2(1): 47-51.

Kusmiadi, E. (2014). Introduction to Agriculture. In: Definition and History of Agricultural Development. Universitas Terbuka, Jakarta, 1-28.

Matthieu, D.C., Anshu, V. and Alvaro, B. (2018). Agriculture 4.0: The Future of Farming Technology. World Government Summit

Moore, F. and Parai, B.J. (1996). The Green Revolution. Unpublished. Retrieved March, 27 2019. From http://docs.google.com/ viewer?a=v\&q=cache:4uMc21GENfkJ:www.ucalgary.ca/ pfitzger/ green.pdf+FitzgeraldMoore,+P.+and+Parai,+B.J\&hl=en\&gl=uk\&pid=bl\&srci $\mathrm{d}=$ ADGEESgJxOUsNC_SQu5d7v59_5eYxN7j_7ffPaJn8rQjnpbKnJYKqARkO 9cjDI7Nx9OZg1H7jRbNJDeJORFPaZ3_3eNPsiPT-rxryh

Luqman, M., Yaseen, M., Ashraf, S., Mehmood, M.U. and Karim, M. (2019). Factors Influencing Use of Information and Communication Technologies among Farmers in Rural Punjab, Pakistan. Journal of Agricultural Extension, 23 (2): 101-112.

Nikola, M., Trendov, Samuel, V. and Meng Z. (2019). Digital Technologies In Agriculture And Rural Areas. Briefing Paper. Food and Agriculture Organization of the United Nations Rome.

Popkova, E.G., Yulia, V., Reagulina and Bogoviz, A.V. 2019. Fundamental Differences of Transition to Industry 4.0 from Previous. Russia (RS): Springer

Rahman, G., Reza Ardakani, M., Bàrberi, P. (2017). Organic Agriculture 3.0 is innovation with research. Organic Agriculture, 7:169-197, https://doi.org/10.1007/s13165-016-0171-5

Reardon, T. and Timmer, C.P. (2012). The Economics of the Food System Revolution. The Annual Review of Resource Economics, 4(14): 1-40.

Sideridis, A.B., Koukouli, M. and Antonopoulo, E. (2010). ICT and farmers: lessons learned and future developments. Journal of Agricultural Informatics, 1(2): $35-$ 41.

Soekartawi. (2007). E-agribusiness: theory and its applications. National Seminar on Information Technology Applications (SNATi) 2007; 2007 June 16; Yogyakarta, Indonesia. Yogyakarta (ID): Universitas Islam Indonesia. 19-25; Retrieved 2018 Mar 3 from http://journal.uii.ac.id.

Steinberg, D. (2012). The Kickstarter Handbook: Real-Life Success Stories of Artists, Inventors, and Entrepreneurs; Quirk Books: Philadelphia, PA, USA.

Taragola, N. and Gelb, E. (2005). Information and Communication Technology (ICT) adoption in horticulture: a comparison to the EFITA Baseline. Proceedings of the EFITA/WCCA 2005 Joint Conference Vila Real, Portugal (PT): Universidade De Tras-os-Montes e Alto Dour.

Haryanto, Y., Sumardjo, Amanah S. and Tjitropranoto P. (2017). The Effectiveness of the Role of Self-Helping Trainers in Empowering Farmers in West Java Province. Journal of Study and Development Agricultural Technology, 20(2): 141-154

Yudiarini, N. (2011). The change from traditional subsistence agriculture to commercial agriculture. Wijen AGRO, 2(1)

Walter, A., Finger, R., Huber, R. and Buchmann, N. (2017). Opinion: Smart farming is key to developing sustainable agriculture. Proceeding of National Academy Science, 114: 6148-6150. 